\title{
PENGEMBANGAN SOAL-SOAL KIMIA BERMUATAN NILAI-NILAI UNTUK MEMPERKOKOH KARAKTER SISWA SMA
}

\author{
Sulastri ${ }^{*}$, Rusman ${ }^{1}$ dan Asria Arifa ${ }^{1}$ \\ 1 Program Studi Pendidikan Kimia, Fakultas Keguruan dan Ilmu Pendidikan, Universitas \\ Syiah Kuala, Jalan Tgk Hasan Krueng Kalee, Darussalam Banda Aceh, 23111, Indonesia \\ *E-mail: sulastri@fkip.unsyiah.ac.id
}

\begin{abstract}
ABSTRAK
Telah dilakukan penelitian pengembangan soal-soal kimia materi hidrokarbon dan minyak bumi bermuatan nilai-nilai (Value based Questions-VBQs) untuk menyediakan alternatif alat evaluasi pembelajaran kimia yang memiliki muatan literasi untuk memperkokoh karakter siswa SMA. Penelitian ini bertujuan untuk menghasilkan soal-soal kimia SMA bermuatan nilai-nilai karakter. Nilai-nilai yang terdapat pada soal yang dikembangkan adalah nilai-nilai: intelektual, spiritual, etika, estetika, sosial dan ekonomi. Penelitian ini menggunakan metode penelitian dan pengembangan melalui tahapan pendefinisian, analisis materi dan indikator (define), desain soal (design) dan pengembangan soal (develop). Subjek penelitian yaitu siswa SMAN 1 Banda Aceh kelas IX yang diambil secara purposive sampling dan jumlah siswa yang terlibat pada tahap diseminasi sebanyak 15 orang untuk melihat keberterimaan siswa terhadap soal. Soal yang telah dikembangkan divalidasi oleh pakar pendidikan kimia dan guru MGMP kimia kota Banda Aceh. Hasilnya menunjukkan bahwa soal yang dikembangkan layak untuk diujicobakan pada siswa. Rata-rata hasil penilaian kelayakan soal sebesar $87 \%$. Hasil tanggapan keberterimaan soal oleh peserta didik menunjukkan persentase sangat setuju sebesar $30 \%$, setuju $50 \%$, tidak setuju $20 \%$ dan sangat tidak setuju $0 \%$. Berdasarkan hasil penelitian dapat disimpulkan soalsoal bermuatan nilai yang dikembangkan dapat diterima oleh guru, layak diaplikasikan dan dipergunakan untuk mengukur hasil belajar siswa. Perlu penelitian lanjutan untuk mengembangkan soal-soal bermuatan karakter bagi materi-materi ajar mata pelajaran kimia lainnya.
\end{abstract}

Kata kunci: pengembangan soal, soal kimia bermuatan nilai, nilai karakter, karakter siswa.

\begin{abstract}
Research and development for develop of hydrocarbon and petroleum value based questions (VBQs) has been conducted to provide alternative chemistry learning test instruments that have literacy content to strengthen the character of high school students. This study aims to obtain chemistry questions from high school VBQs. The values contained in the questions developed are values: intellectual, spiritual, ethical, aesthetic, social and economic. This study uses a research and development (R\&D) method through define, design and develop stages. The research subjects were class IX students of SMAN 1 Banda Aceh who were taken by purposive sampling and the number of students involved in the dissemination stage were 15 people to study students' acceptance of the questions. VBQs that have been developed were validated by chemistry education experts and teachers of the Banda Aceh city chemical MGMP. The results show that VBQs developed are feasible to be tested on students. The average VBQs feasibility assessment results are $87 \%$. The results of VBQs acceptance responses by students showed a percentage of strongly agreed by $30 \%$, agreed $50 \%$, did not agree $20 \%$ and strongly disagreed $0 \%$. Based on the results of the study it can be concluded that the VBQs developed can be accepted by the teacher, are feasible to be applied and used to measure student learning outcomes. Further research is needed to develop VBQs for teaching materials in other chemical subjects.
\end{abstract}

Keyword: development of questions, values based questions, values, character of students.

DOI: https://doi.org/10.15575/jtk.v3i2.3512 


\section{PENDAHULUAN}

Pendidikan nasional secara umum bukanlah hanya untuk mencerdaskan peserta didik dalam pengetahuan tetapi sikap dan perilaku siswa juga menjadi perhatian utama apalagi dalam kondisi era global di mana banyak kasus terjadinya penurunan nilai-nilai kemanusiaan, moral, dan karakter peserta didik yang buruk dalam segala aspek kehidupan berbangsa dan bernegara saat ini setiap hari dapat kita saksikan di media massa. Oleh karenanya, pendidikan yang diharapkan mampu menghasilkan manusia yang cerdas pengetahuan, baik dalam bersikap dan santun dalam berperilaku atau disebut sebagai individu yang berkarakter (Ghufron, 2010).

Kurikulum 2013 yang juga dikenal sebagai kurikulum berbasis karakter menekankan pentingnya pengembangan karakter-karakter baik dari peserta didik melalui kegiatan pembelajaran di sekolah baik melalui kegiatan intra, ko maupun ekstra kurikuler. Sebagaimana diilustrasikan dalam matriks strategi mikro integrasi karakter pada grand design pendidikan karakter nasional, bahwa integrasi karakter dilakukan melalui kegiatan belajar mengajar pada mata pelajaran. Upaya integrasi karakter melalui pembelajaran telah banyak diujicobakan, termasuk juga melalui kegiatan belajar mengajar kimia di SMA.

Ilmu kimia bukanlah semata-mata hanya mengandung teori, konsep, hukum, faktafakta dan prosedur kimia sebagai ilmu pengetahuan saja tetapi ilmu kimia juga mengandung muatan nilai-nilai: spiritual, intelektual, etika, estetika, sosial, ekonomi dan politik di dalamnya. Di dalam materi kimia juga terdapat ayat-ayat kauniyah yang menjadi pelajaran spiritual untuk mendekatkan diri kepada Allah Sang Maha Pencipta. Nilai-nilai ini memerlukan pengemban untuk sampai kepada penggunanya. Dalam pendidikan, guru adalah pengemban nilai yang memahamkan peserta didik sebagai pengguna ilmu untuk menghayati dan mengamalkan nilai-nilai ini dalam sikap dan perilakunya sehari-hari (Yudianto, 2005). Pendidik yang mampu membelajarakan peserta didiknya untuk memahami ilmu kimia dan memahami nilainilai di dalamnya telah melaksanakan kegiatan belajar mengajar berkualitas. Pembelajaran yang dilakukannya disebut pembelajaran bermuatan nilai. Pembelajaran konsep tanpa disertai dengan pembelajaran nilai akan membentuk peserta didik yang bebas nilai. Pendidikan yang bebas nilai akan melahirkan peserta didik yang cerdas tetapi meninggalkan nilai-nilai kemanusiaan dalam kehidupannya (Lovat, 2009). Pembelajaran bermuatan nilai membutuhkan juga tersedianya soal-soal kimia bermuatan nilai sebagai instrumen pengukuran hasil belajarnya.

Meskipun pemberlakuan kurikulum 2013 sudah berlangsung beberapa tahun, tetapi ketersedian soal-soal bermuatan nilai untuk materi ajar kimia masih sangat sedikit. Analisis terhadap buku kimia SMA dari beberapa penerbit yang sering dijadikan sumber belajar kimia di SMA, dijumpai masih minim sekali soal-soal kimia bermuatan nilai. Saat ini di India telah banyak beredar soal-soal kimia bermuatan nilai. Sebagai contoh bagaimana soal-soal bermuatan nilai yang telah digunakan untuk mengukur hasil belajar kimia dapat diakses di website CBSE Class (2018). Soal-soal yang bermuatan nilai, tidak hanya untuk menguji kemampuan konsep kimia, tetapi juga memperkaya wawasan literasi sains, literasi manusia dan literasi-literasi lainnya yang memperkokoh penguasaan nilai dan pembiasaan perilaku-perilaku baik siswa dalam kehidupan sehari-hari melalui pembelajaran kimia.

Berdasarkan uraian di atas, dilakukanlah penelitian Riset dan Pengembangan ( $R \& D)$ untuk menghasilkan soal-soal kimia pada materi hidrokarbon dan minyak bumi yang didalamnya terkandung nilai-nilai pembelajaran sehingga diharapkan peserta didik tidak hanya memiliki kompetensi pengetahuan tentang materi hidrokarbon dan minyak bumi namun juga dapat memiliki kompetensi sikap dan perilaku yang sesuai dengan nilai-nilai yang dapat menghasilkan karakter yang baik untuk kehidupan. 


\section{METODE PENELITIAN}

Penelitian ini merupakan penelitian pengembangan Research and Development $(R \& D)$ yang menghasilkan produk tertentu dan menguji keefektifan produk yang dihasilkan (Sugiyono, 2012). Metode $R \& D$ yang diadopsi dalam penelitian meliputi tahap define (pendefinisian), design (perencanaaan), dan develop (pengembangan).

Uji coba produk penelitian ini dilaksanakan di SMA Negeri 1 Banda Aceh yang terletak di Jl. A. Majid Ibrahim 1 No. 7, Desa Punge Jurong Meraxa, Kota Banda Aceh. Pemilihan sekolah ini karena visi SMAN 1 Banda Aceh yaitu mempersiapkan lulusan yang cerdas intelektual, emosional, dan spiritual, serta berkarakter madani. Sekolah memerlukan soal-soal pembelajaran kimia bermuatan nilai, sekolah subjek penelitian sudah menerapkan integrasi karakter dalam pembelajaran tetapi belum memiliki soal-soal bermuatan nilai yang valid dan reliabel untuk dipergunakan sebagai instrumen tes. Koesoema (2007) menjelaskan bahwa lembaga pendidikan seperti sekolah memiliki cita-cita seperti menetapkan visi pendidikan karakter, jika tidak menetapkan visi sekolah maka pengembangan pendidikan karakter akan menjadi suatu kesia-siaan. Sampel sebanyak 15 siswa kelas XI MIA 4 diminta memberikan tanggapan siswa terhadap soal yang dikembangkan. Validasi penilaian kelayakan soal-soal bermuatan nilai dilakukan oleh dosen ahli dan guru-guru kimia pada MGMP kimia Banda Aceh.

\section{HASIL DAN PEMBAHASAN}

Tahapan pengembangan soal bermuatan nilai dimulai dengan tahap pendefinisian, peneliti menganalisis soal-soal yang dapat diintegrasikan dengan nilai-nilai karakter. Kegiatan ini diawali dengan menganalisis soal-soal yang terdapat dalam buku ajar kimia SMA. Peneliti menemukan bahwa soal-soal kimia SMA belum bermuatan nilai-nilai pembelajaran, soal-soal yang terdapat di dalam buku ajar kimia SMA hampir semuanya redaksi kalimatnya langsung to the point pada materi kimia, belum menggunakan soal kimia dari kasus nyata dalam kehidupan sehari-hari yang memiliki pesan nilai atau moral untuk memberi contoh perilaku baik, atau dapat dikatakan soal-soal yang ada masih bebas nilai. Berbeda halnya dengan soal-soal yang terdapat dalam buku teks kimia yang digunakan oleh negara-negara anggota (Organization for Economic Co-operation and Development-OE(D), misalnya pada buku kimia "Chemistry $A$ Course for $O$ Level" (Presscott, 2005), dan juga soal-soal yang dikembangkan di beberapa negara di luar negeri (Sangathan, 2012).

Pada tahap pendefinisian ini, peneliti mendefinisikan nilai-nilai yang akan diintegrasikan pada materi hidrokarbon dan minyak bumi. Nilai-nilai akan diintegrasikan diantaranya nilai spiritual, nilai etika, nilai estetika, nilai ekonomi dan nilai intelektual. Integrasi nilai-nilai ini bertujuan untuk mempertegas dan meperkokoh karakter peserta didik untuk lebih memiliki kesadaran akan kebesaran Allah SWT, peduli lingkungan, memiliki kemampuan intelektual, memiliki rasa estetika dan etika, memiliki kemampuan literasi yang baik, dan kemampuan bersosialisasi dengan masyarakat, serta karakter-karakter universal lainnya sebagai manusia yang hidup di abad 21. Sesuai dengan penelitian pengembangan yang dikemukakan oleh Trianto (2009).

Tahap kedua adalah tahap perancangan soal, peneliti terlebih dahulu menyiapkan perangkat pembelajaran untuk mengetahui cara yang efektif dan efisien untuk mengembangkan rancangan produk awal berdasarkan informasi-informasi yang telah diperoleh pada tahap pendefinisian. Soal bermuatan nilai yang dikembangkan juga diarahkan untuk menumbuhkan kesadaran moral yang lebih baik pada peserta didik agar semakin mencintai ilmu kimia yang banyak manfaatnya dalam kehidupan sehari-hari.

Tahap ketiga adalah pengembangan merupakan tahap untuk menghasilkan produk atau soal-soal yang bermuatan nilai. Soal kimia kelas XI semester 1 hanya dikembangkan pada penelitian ini yaitu pada 
materi hidrokarbon dan minyak bumi dalam soal uraian. Nilai yang paling utama diintegrasikan dalam soal ini adalah nilai religius. Nilai religius dalam IPA adalah kandungan nilai yang dapat meningkatkan keyakinan terhadap Allah SWT. Seandainya seorang muslim berpegang teguh pada AlQur'an dan hadis maka mempelajari sains dengan baik merupakan hal yang wajib (Sauri, 2010).

Soal yang berhasil dikembangkan dengan nilai-nilai berjumlah 18 soal. Hasil akhir dari pengembangan adalah sebagai berikut:

Soal nomor 1 (satu) tentang materi hidrokarbon pada KD 3.1 dan indikator dikembangkan dengan bermuatan nilai-nilai diantaranya nilai spiritual, nilai estetika, dan nilai intelektual. Nilai spiritual dari soal tersebut adalah terdapatnya kesadaran atas kebesaran Allah SWT yang bertujuan mengajak peserta didik untuk mengetahui apapun yang dipelajari tidak terlepas dari ciptaan Allah. Nilai estetika dalam soal tersebut adalah setiap individu memiliki sifat khasnya masing-masing bahkan saudara kembar sekalipun tetap memiliki perbedaan sifat, sedangkan nilai intelektual tertuang dalam konsep tentang sifat khas atom karbon yang ditanyakan dalam soal.

Soal nomor 2 (dua) dikembangkan pada materi hidrokarbon KD 3.1 dan indikator kesatu, soal yang telah dikembangkan mengandung nilai spiritual, nilai intelektual, nilai ekonomi dan nilai estetika. Terintegrasinya nilai spiritual dalam soal tersebut dapat dilihat dari pemberitahuan tentang begitu luasnya tersebar kekuasaan Allah di alam semesta ini yang mengajak peserta didik untuk menyadari keteraturan tersebut. Jika seseorang telah mempelajari dan mengerti nilai, maka nilai tersebut cepat atau lambat akan mempengaruhi keyakinannya, sehingga nilai akan menjadi dasar pemikiran sebelum seseorang seseorang tersebut melakukan tindakan (Hakam, 2008).

Soal yang dikembangkan pada nomor 3 (tiga) yaitu materi hidrokarbon KD 3.1 dan indikator kedua, soal tersebut mengandung nilai intelektual, nilai estetika, dan nilai sosial. Nilai intelektual memberikan informasi kepada peserta didik bahwa keterkaitan antara pelajaran yang diperoleh ketika di lampu merah dan materi yang dipelajari. Nilai estetika dari soal adalah ketertiban dari pengguna jalan untuk tetap mematuhi peraturan yang telah disampaikan, membuat peserta didik memahami bahwa peraturan bukan hanya disampaikan dan dijalankan tetapi peraturan juga berdampak bagi masing-masing individu jika tidak dilaksanakan, hal ini berkaitan pula dengan nilai sosial.

Soal nomor 4 (empat) yaitu soal yang dikembangkan pada materi hidrokarbon pada KD 3.1 dan indikator kedua. Soal tersebut diintegrasikan dengan nilai-nilai diantaranya nilai intelektual, nilai etika dan nilai ekonomi. Nilai intelektual yang terkandung dalam soal yaitu terletak pada pengetahuan tentang plastik yang berdampak buruk bagi kesehatan dan lingkungan yang menimbulkan pencemaran, nilai etika yaitu membuat peserta didik sadar akan seorang siswa yang harus mengajak masyarakat untuk menghindari pembakaran plastik dan menghemat penggunaan plastik, sedangkan nilai ekonomi dalam soal tersebut yaitu manfaat akan menggunakan plastik yang ramah lingkungan.

Soal nomor 5 (lima) untuk materi hidrokarbon KD 3.1 dan indikator ketiga. Nilai yang terkandung dalam soal adalah nilai intelektual, nilai ekonomi, dan nilai estetika. Kandungan nilai intelektual yaitu kecerdasan peserta didik untuk memahami ilmu yang diperoleh sebelum mengerjakan soal, nilai ekonomi terdapat pada manfaat atau kegunaan daripada senyawa hidrokarbon, dan nilai estetika dalam soal yaitu keteraturan dalam mengerjakan soal tersebut.

Soal nomor 6 (enam) tersebut dikembangkan pada materi hidrokarbon KD 3.1 dan indikator keempat, nilai yang terkandung dalam soal tersebut diantaranya nilai spiritual, nilai intelektual, dan nilai etika. Nilai spiritual terdapat pada kewajiban yang dicerminkan 
seorang anak dalam beribadah tanpa ada suruhan dari orang tuanya. Kemudian nilai intelektual terdapat pada pengetahuan perbedaan senyawa hidrokarbon berdasarkan perbedaan kejenuhan ikatan, selanjutnya nilai etika terdapat pada pertanyaan yang ditugaskan kepada peserta didik.

Soal nomor 7 (tujuh) dikembangkan pada materi hidrokarbon KD 3.1 indikator kelima, nilai yang diintegrasikan pada soal tersebut diantaranya nilai spiritual, nilai intelektual, dan nilai estetika. Nilai spiritual terdapat pada kekuasaan Allah yang telah menciptakan manusia secara berpasang-pasangan. Nilai intelektual yaitu pada pengetahuan tentang senyawa hidrokarbon juga dikelompokkelompokkan agar mudah diketahui namanya dan kegunaannya, sedangkan nilai estetika terdapat pada keteraturan akan senyawa kimia dapat dipergunakan dengan nyaman dan aman jika sudah dikenali dengan baik.

Materi dalam soal nomor 8 (delapan) yaitu hidrokarbon KD 3.1 dari indikator kelima, serta nilai-nilai yang diintegrasikan pada soal tersebut yaitu nilai intelektual, dan nilai estetika. Terintegrasinya nilai intelektual dalam soal tersebut terletak pada pemahaman peserta didik tentang penamaan senyawa hidrokarbon secara sistematis dan pengelompokkan senyawa hidrokarbon ternyata dapat dipelajari kemudahan dalam kehidupan sehari-hari dalam memilih barang yang dibutuhkan ketika berbelanja. Kemudian nilai estetika terletak pada pendapat peserta didik tentang penamaan senyawa hidrokarbon secara sistematis.

Materi dalam soal nomor 9 (sembilan) yaitu hidrokarbon KD 3.1 dan indikator keenam, serta nilai-nilai yang diintegrasikan pada soal tersebut yaitu nilai religius, nilai estetika, dan nilai sosial. Terdapatnya nilai religius dalam soal tersebut dapat dilihat dari pelajaran yang dapat diambil dari tuntutan islam untuk saling menyayangi dan menghindari permusuhan, nilai estetika terdapat pada setiap makhluk ciptaan Allah memiliki keistimewaanya masing-masing terkait pula perbedaan keistimewaa pada senyawa hidrokarbon, kemudian nilai sosial terdapat pada pelajaran dari soal untuk saling berinteraksi walaupun berbeda-beda antara satu individu dan individu lainnya.

Materi dalam soal nomor 10 (sepuluh) dari hidrokarbon KD 3.1 dan indikator ketujuh, serta nilai-nilai yang diintegrasikan pada soal tersebut yaitu nilai religius, nilai sosial, dan nilai ekonomi. Nilai religius terdapat pada perintah Allah dalam Al-Qur'an untuk senantiasa tolong-menolong. Nilai sosial juga terdapat pada kebersamaan dalam kebaikan bukan dalam keburukan, sedangkan nilai ekonomi terletak pada pemanfaatan senyawa hidrokarbon dengan berbagai reaksi yang dapat terjadi.

Materi dalam soal nomor 11 (sebelas) yaitu minyak bumi KD 3.2 dan indikator kesatu, serta nilai-nilai yang diintegrasikan pada soal tersebut yaitu nilai religius, nilai ekonomi, nilai etika dan nilai intelektual. Nilai religius terdapat pada bukti perintah Allah dalam surat Al-Qur'an untuk mensyukuri nikmat yang telah Allah berikan, nilai ekonomi dapat dilihat pada pemanfaatan minyak bumi untuk kemakmuran manusia, kemudian nilai etika membuat peserta didik untuk memiliki kesadaran agar dapat menggunakan minyak bumi tersebut dengan sebaik-baiknya serta nilai intelektual untuk membuat peserta didik memiliki pengetahuan tentang pembentukan minyak bumi dan cara mengeksplorasinya.

Hasil pengembangan soal nomor 12 yaitu pada materi minyak bumi indikator kedua bermuatan nilai-nilai diantaranya nilai intelektual, estetika, dan nilai ekonomi. Terdapatnya nilai intelektual dalam soal tersebut dapat dilihat dari informasi penjelasan tentang minyak bumi, nilai estetika terletak pada pemahaman peserta didik tentang pemisahan minyak bumi dari sumbernya dan dihasilkan fraksi-fraksi, selanjutnya nilai ekonomi adalah kegunaan dari berbagai fraksi-fraksi minyak bumi.

Soal nomor 13 yaitu soal yang dikembangkan pada materi minyak bumi pada KD 3.2 dan indikator kedua. Nilai-nilai yang dikembangkan dalam soal tersebut diantaranya nilai intelektual, nilai estetika, dan 
nilai ekonomi. Terintegrasinya nilai intelektual dalam soal yaitu pengetahuan peserta didik tentang tahap pengolahan minyak bumi, nilai estetika juga keteraturan pengelompokkan proses pengolahan minyak bumi berdasarkan titik didih dan jumlah atom karbon pembentuk rantai karbonnya, selanjutnya nilai ekonomi terletak pada pengolahan minyak bumi untuk pemanfaatan hidup manusia.

Soal nomor 14 yaitu soal yang dikembangkan pada materi minyak bumi pada KD 3.2 dan indikator ketiga. Nilai-nilai yang dikembangkan dalam soal tersebut diantaranya nilai religius, nilai etika, dan nilai ekonomi. Terkandungnya nilai religius dalam soal tersebut dapat dilihat dari firman Allah dalam ayat suci Al-Qur'an tentang apa yang ada di bumi dapat dimanfaatkan dengan sebaik-baiknya, nilai etika yaitu kesadaran peserta didik untuk dapat memanfaatkan sesuatu dengan benar, kemudian nilai ekonomi menekankan pada kegunaan fraksifraksi minyak bumi.

Soal nomor 15 yaitu soal yang dikembangkan pada materi minyak bumi pada KD 3.3 dan indikator kesatu. Nilai-nilai yang dikembangkan dalam soal tersebut diantaranya nilai religius, nilai etika, dan nilai ekonomi. Nilai religius dapat dilihat dari ketegasan Allah dalam melarang manusia untuk berbuat kerusakan di muka bumi. Nilai etika yaitu perilaku peserta didik untuk menghindari pencemaran akibat pembakaran bahan bakar yang tidak dipergunakan sebagaimana mestinya, kemudian nilai ekonomi terkandung sebagai pemanfaatan minyak bumi.

Soal nomor 16 yaitu soal yang dikembangkan pada materi minyak bumi pada KD 3.3 dan indikator kesatu. Nilai-nilai yang diintegrasikan dalam soal diantaraya nilai intelektual, nilai etika, dan nilai ekonomi. Nilai intelektual dalam soal tersebut dilihat dari pemahaman peserta didik mengenai angka oktan dalam bahan bakar yang menunjukkan mutu bensin, nilai etika membuat mereka paham akan kesadaran akan dampak dari penambahan TEL dan cara mengatasinya, kemudian nilai ekonomi dapat memberikan manfaat dari solusi penggunakan alternatif lain untuk menaikkan angka oktan pada bahan bakar.

Soal nomor 17 yaitu soal yang dikembangkan pada materi minyak bumi pada KD 3.3 dan indikator kedua. Nilai yang diintegrasikan dalam soal diantaranya nilai etika, nilai intelektual. Nilai etika yaitu kesadaran peserta didik akan pengaruh besar jika melakukan pemborosan bahan bakar terhadap lingkungan dan kesehatan, sedangkan nilai intelektual yaitu mengerti akan bahaya serta dampak yang ditimbulkan dari asap kendaraan terhadap lingkungan dan kesehatan.

Soal nomor 18 yaitu soal yang dikembangkan pada materi minyak bumi pada KD 3.3 dan indikator kedua. Nilai yang diintegrasikan dalam soal diantaranya nilai intelektual dan nilai etika. Nilai intelektual terdapat pada pengetahuan tentang pembakaran sempurna dan pembakaran tidak sempurna pada bahan bakar, sedangkan nilai etika terletak pada kesadaran peserta didik untuk dapat menghemat bahan bakar.

\subsection{Hasil Validasi Kelayakan Soal dan Tanggapan Peserta Didik terhadap Soal}

\subsubsection{Hasil Penilaian Kelayakan Soal}

Soal-soal yang telah dikembangkan melalui tahap define, design, dan develop, dilakukan penilaian untuk memperoleh informasi kelayakannya. Penilaian kelayakan soal melibatkan dosen ahli dan delapan orang guru kimia peserta MGMP kota Banda Aceh. Hasil persentase uji kelayakan rata-rata sebesar $87 \%$ termasuk dalam kategori sangat layak. Hal tersebut menunjukkan bahwa soal-soal bermuatan nilai layak untuk menjadi pegangan guru dan dapat diuji pada siswa SMA kelas XI. Grafik hasil penilaian kelayakan soal bermuatan nilai dapat dilihat pada Gambar 1 berikut. 


\section{Hasil Penilaian Kelayakan Soal}

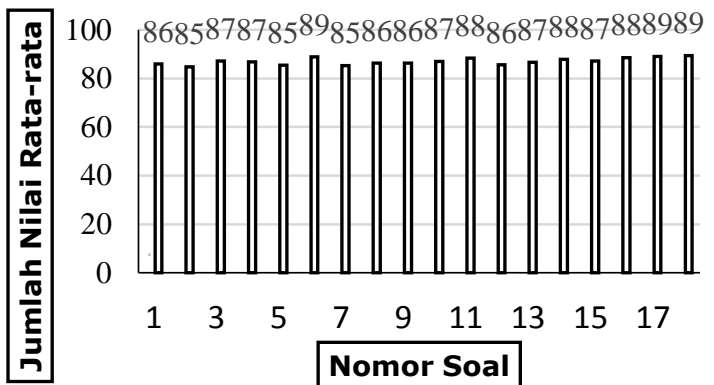

Gambar 1. Grafik Hasil Penilaian Kelayakan Soal Bermuatan Nilai

Gambar 1 menunjukkan bahwa hasil validasi soal bermuatan nilai karakter mendapatkan nilai rata-rata $87 \%$ dengan kategori sangat layak. Hal tersebut menunjukkan bahwa soal bermuatan nilai karakter layak untuk diujicobakan dan dapat menjadi pegangan guru untuk mengukur kemampuan peserta didik dan menumbuhkan karakter peserta didik dengan soal bermuatan nilai karakter.

\subsubsection{Tanggapan Peserta Didik Setelah Peserta Didik Menjawab Soal}

Soal kimia bermuatan nilai, diberikan kepada peserta didik, setelah peserta didik menjawab soal bermuatan nilai, mereka memberikan tanggapan. Ada sebelas tanggapan peserta didik dapat dilihat pada Gambar 2.

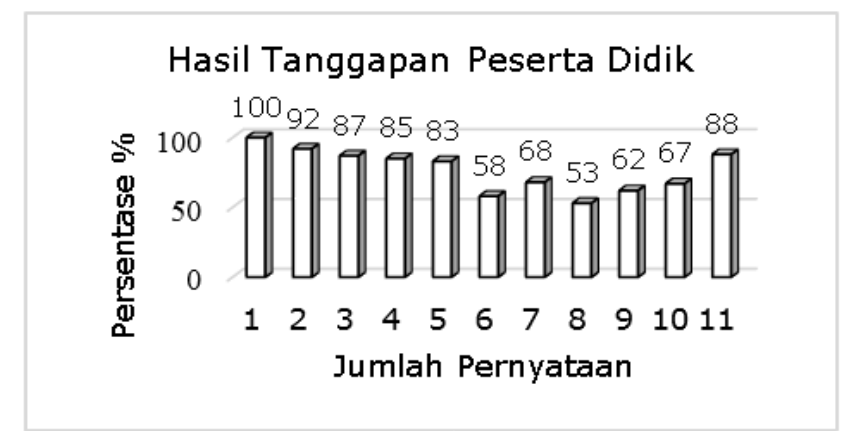

\section{Gambar 2. Hasil Tanggapan Peserta Didik terhadap Soal}

Gambar 2 menunjukkan bahwa peserta didik setuju dengan soal yang dikembangkan, dengan persentase rata-rata $80 \%$ pada pernyataan ke-1, 2, 3, 4, 5, 7, 9, 10 dan 11 , sedangkan pada pernyataan ke- 6 dan ke-8 mendapat rata-rata persentase $55 \%$, hal tersebut menunjukkan bahwa peserta didik setuju dengan soal bermuatan nilai yang telah dikembangkan. Menurut (Sugiyono, 2012) bahwa pemberian skor angket tanggapan peserta didik apabila diperoleh nilai $80-100 \%$ maka nilai tersebut termasuk dalam kategori sangat setuju. Penjelasan dari tanggapan peserta didik adalah sebagai berikut:

(1) Pernyataan pertama yaitu jumlah persentase tanggapan peserta didik terhadap soal sebesar $100 \%$, pernyataan tersebut tentang soal bermuatan nilai karakter membuat saya menyadari dan mensyukuri atas kekuasaan dan rahmat Allah SWT.

(2) Pernyataan kedua yaitu soal bermuatan nilai karakter dapat meningkatkan karakter saya terhadap rasa tanggung jawab saya sebagai siswa, nilai persentase peserta didik yaitu $92 \%$.

(3) Pernyataan ketiga yaitu tentang proaktif, jujur dan disiplin, terlihat jelas peserta didik setuju atas kebutuhan yang diperoleh dalam soal untuk lebih bersikap proaktif, nilai persentase pada pernyataan tersebut sebesar $87 \%$.

(4) Pernyataan keempat membahas tentang dapat menempatkan diri sebagai cerminan yang baik dalam pergaulan, persentase pada pernyataan ini sebesar $85 \%$, dapat dilihat bahwa peserta didik setuju atas pernyataan tersebut yang melibatkan dirinya untuk menjadi cerminan yang baik dalam pergaulan.

(5) Pernyataan kelima yaitu soal bermuatan nilai karakter dapat meningkatkan kesadaran saya terhadap lingkungan, persentase yang diperoleh yaitu $83 \%$. Tujuan diadakannya pendidikan nilai itu ialah untuk selalu membuat peserta didik dapat berpikir logis dalam menghadapi masalah-masalah yang 
dijumpai dalam kehidupan (Adisusilo, 2012).

(6) Pernyataan keenam yaitu pertanyaan dalam soal disajikan lebih bervariasi dan menyenangkan sehingga memudahkan saya dalam menjawab soal, persentase yang diperoleh sebesar 58\%. Soal bermuatan nilai karakter yang disajikan berbentuk uraian yang diawalnya terdapat pengetahuan sebelum mengerjakan soal, persentase yang rendah tersebut dapat disebabkan oleh soal yang panjang sehingga membuat peserta didik merasa bosan untuk membaca soal.

(7) Pernyataan ketujuh tentang muatan nilai karakter yang disajikan dalam soal telah sesuai dengan materi hidrokarbon dan minyak bumi, dan persentase yang diperoleh yaitu sebesar $68 \%$.

(8) Pernyataan kedelapan membahas tentang tampilan soal yang disajikan menarik dan persentase peserta didik yaitu sebesar 53\%, hal tersebut berhubungan dengan pernyataan keenam, peserta didik merasa tampilan soal yang disajikan kurang menarik karena terlalu panjang.

(9) Pernyataan kesembilan tentang penggunaan bahasa yang digunakan pada soal baik dan mudah dipahami diperoleh persentase sebesar $62 \%$.

(10) Pernyataan kesepuluh tentang gambar pada soal terlihat jelas dan memudahkan saya dalam memahami soal tersebut, persentase yang didapat yaitu $67 \%$.

(11) Pernyataan kesebelas yaitu tentang seluruh cakupan pada soal telah memuat nilai-nilai pembelajaran, persentase yang diperoleh yaitu $88 \%$.

Persentase tanggapan peserta didik dapat dinyatakan dalam Gambar 3.



Gambar 3. Persentase Hasil Tanggapan Peserta Didik

Gambar 3 menjelaskan bahwa persentase setuju siswa terhadap soal bermuatan nilai sebesar $80 \%$, dan persentase tidak setuju sebesar 20\% serta persentase sangat tidak setuju sebesar $0 \%$. Ketidaksetujuan peserta didik atau rendahnya angka persentase terdapat pada pernyataan keenam tentang pertanyaan dalam soal disajikan lebih bervariasi dan menyenangkan sehingga memudahkan dalam menjawab soal. Persentase yang rendah juga terdapat pada pernyataan kedelapan yaitu tentang tampilan soal yang disajikan menarik, melalui investigasi lebih lanjut diperoleh informasi dari peserta didik bahwa hal tersebut dikarenakan soal bermuatan nilai yang telah dikembangkan disajikan menggunakan redaksi kalimat yang panjang sehingga membuat peserta didik kurang bersemangat dalam mengerjakan soal.

Beberapa contoh soal hasil pengembangan disajikan sebagai berikut:

Contoh 1 (produk pengembangan nomor dua):

"Jika kita terus mencari dan mau mempelajari dengan sungguh-sungguh, ternyata begitu banyak kekuasaan Allah yang tersebar di alam semesta ini. Seperti halnya dalam kelompok senyawa hidrokarbon terdapat gas $\mathbf{X}$. Gas $\mathbf{X}$ ini bisa menjadi ancaman bagi planet bumi karena dapat memicu pemanasan global tetapi pada sisi lainnya gas $\mathbf{X}$ ini bermanfaat sebagai sumber bahan bakar. Gas $\mathbf{X}$ secara alamiah dapat dihasilkan dari proses pembusukan an-aerob dan aktivitas makhluk 
hidup, baik manusia, hewan, maupun tumbuhan.

a. Gas apakah yang dimaksud dalam uraian di atas?

b. Beserta tuliskan rumus strukturnya?

c. Bagaimanakah sikap Anda setelah mengetahui begitu luasnya kekuasaan Allah?

Berilah satu contoh hal lain yang kalian dapatkan dalam kehidupan sehari-hari tentang senyawa hidrokarbon yang sangat bermanfaat bagi kehidupan sebagi bukti luasnya kekuasaan Allah?"

Contoh 2 (produk pengembangan nomor tiga):

Andi sedang berlibur di suatu kota. Ketika berhenti di lampu merah, Andi membaca pemberitahuan yaitu "Hentikan mesin kendaraan di lampu merah untuk menghemat bahan bakar".

a. Jika Anda yang menjadi Andi, apa yang akan Anda lakukan?

b. Menurut Anda, mengapa mesin kendaraan harus dimatikan di lampu merah?

c. Sebutkan unsur yang terkandung pada pembakaran tersebut?

d. Apakah Anda setuju dengan peraturan yang ditampilkan di lampu merah? Jelaskan!

Contoh 3 (produk pengembangan nomor 4): Akhir-akhir ini, plastik sudah lazim digunakan sebagai wadah tempat mengisi barang belanjaaan. Umumnya Plastik merupakan senyawa organik yang dibuat dari proses sintesis. Plastik bersifat tidak biodegradasi, artinya plastik tidak dapat diurai oleh organisme hidup. Salah satu cara mudah yang sering dilakukan masyarakat untuk mengurangi sampah plastik dengan cara membakar plastik tersebut.

a. Tuliskan hasil pembakaran dari plastik?

c. Bagaimana tanggapan Anda terhadap fenomena masyarakat membakar plastik? d. Bagaimanakah efek terhadap lingkungan dan kesehatan?

e. Bagaimana mengatasi masalah pencemaran lingkungan oleh plastik?

Contoh 4 (produk pengembangan nomor 10): Allah telah menjelaskan dalam Al-Qur'an bahwa segala sesuatu kebaikan apabila dilakukan dengan bersama-sama maka akan mudah. "Dan tolong-menolonglah kamu dalam (mengerjakan) kebajikan dan takwa, dan jangan tolong-menolong dalam berbuat dosa dan pelanggaran. Dan bertakwalah kamu kepada Allah, sesungguhnya Allah amat berat siksa-Nya" (QS. Al-Maaidah: 2). Ayat tersebut adalah bukti nyata kepada manusia bahwa Allah telah menjelaskan agar kita saling tolong menolong dalam hal kebaikan dan janganlah melakukan pelanggaran. Berkaitan dengan ayat tersebut, reaksi kimia organik juga menerapkan prinsip kerja sama dan saling memberi. Senyawa alkena dan alkuna dapat mengalami reaksi adisi yaitu reaksi penghilangan ikatan rangkap karena penambahan zat lain, serta juga macammacam reaksi lainnya seperti adisi, substitusi, eliminasi, oksidasi. Aplikasi dari penjelasan di atas terjadi pada reaksi berikut.

a. Selesaikan reaksi adisi berikut! $\mathrm{CH}_{3} \mathrm{CH}=\mathrm{CH}_{2}+\mathrm{HX} \rightarrow$

b. Tentukanlah jenis reaksi yang terjadi pada persamaan reaksi berikut:

$$
\begin{aligned}
& \mathrm{CH}_{3}-\mathrm{CH}_{2}-\mathrm{CH}_{2} \mathrm{Br}-\mathrm{C}_{2} \mathrm{H}_{5} \mathrm{ONa} \rightarrow \\
& \mathrm{CH}_{3}-\mathrm{CH}_{2}-\mathrm{CH}_{2}-\mathrm{O}-\mathrm{CH}_{2}-\mathrm{CH}_{3}+\mathrm{NaBr} \\
& \mathrm{CH}_{3}-\mathrm{CHBr}-\mathrm{CH}_{3}+\mathrm{NaOH} \rightarrow \\
& \mathrm{CH}_{3}-\mathrm{CH}=\mathrm{CH}_{2}+\mathrm{NaBr}+\mathrm{H}_{2} \mathrm{O} \\
& \mathrm{CH}_{3}-\mathrm{CH}=\mathrm{CH}_{2}+\mathrm{HBr} \rightarrow \mathrm{CH}_{3}-\mathrm{CHBR}-\mathrm{CH}_{3}
\end{aligned}
$$

c. Manakah yang termasuk reaksi adisi, eliminasi dan reaksi substitusi?

d. Bagaimana menurut Anda nilai kerjasama dan tolong menolong melalui saling memberi dan menerima dari reaksi- reaksi tersebut diaplikasikan dalam kehidupan sehari-hari? 


\section{KESIMPULAN}

Berdasarkan hasil penelitian yang telah dilakukan diperoleh bahwa soal-soal bermuatan nilai yang telah dikembangkan divalidasi oleh dosen ahli dan guru MGMP kota Banda Aceh, hasilnya menunjukkan bahwa soal layak untuk diuji cobakan pada siswa dengan rata-rata hasil penilaian kelayakannya adalah $87 \%$. Hasil tanggapan peserta didik terhadap soal-soal menunjukkan keberterimaan yang baik dari peserta didik. Dengan demikian dapat disimpulkan bahwa soal-soal bermuatan nilai karakter pada materi hidrokarbon dan minyak bumi yang telah dikembangkan layak digunakan sebagai alat ukur pembelajaran materi hidrokarbon dan minyak bumi. 


\section{DAFTAR PUSTAKA}

Aprilia, I. T., Murbangun, N. \& Endang, S. (2015). Pengembangan Media Flash Berbasis Pembelajaran Inkuiri Untuk Meningkatkan Hasil Belajar Siswa. Jurnal Inovasi Pendidikan Kimia, 9(2), 16071616.

Adisusilo, S. (2012). Pembelajaran NilaiNilai Karakter. Jakarta: PT Raja Grafindo Persada.

CBSE Class. (2018). (http://www.studiestoday.com/valuebased-questions/103/chemistry.html), diakses pada 05 November 2018.

Ghufron, A. (2010). Integrasi Nilai-Nilai Karakter Bangsa Pada Kegiatan Pembelajaran. Cakrawala Pendidikan, Jurnal Ilmiah Pendidikan, Edisi Khusus Dies Natalis UNY.

Hakam, K. A. (2008). Pendidikan Nilai dalam kajian Filosofi Paedagogis. Bandung: CV. Jasindo Multi Aspek.

Koesoema, D. (2007). Pendidikan Karakter. Jakarta: Gramedia Widiasarana.

Lovat, T. and Ron, T. (2009). Values Education and Quality Teaching: The Double Helix Effect. Netherlands: Springer.

Sauri, S. (2010). Pendidikan Nilai. Bandung: Arfino Raya.

Sugiyono. (2012). Metode Penelitian Kuantitatif, Kualitatif, dan $R$ and $D$. Bandung: Alfabeta.

Trianto. (2009). Mendesain Model Pembelajaran Inovatif progesif. Jakarta: Kencana.

Value Based Question Chemistry XII. (2012). (https://librarykv2calicut.files.wordpress. com/2012/11/value-based-questionsin-chemistry-class-xii.pdf), diakses pada 03 Juli 2017.
Yudianto, S. A. (2005). Manajemen Alam Sumber Pendidikan Nilai. Bandung: Anggota lkapi. 